Convexity and Sheepskin Effects in the Human Capital Earnings Function

\section{Recent Evidence for Filipino Men}

Norbert R. Schady

\author{
Data on education in the \\ Philippines show that there \\ are large differences in the \\ private rate of return to \\ education by level: the wage \\ premia associated with an \\ additional year of schooling \\ are about twice as large at \\ the university level as they are \\ at the primary school level. In \\ addition, there are large \\ "sheepskin effects." \\ Completion of the last year of \\ schooling within a given level \\ is rewarded dispropor- \\ tionately, particularly for \\ university graduates.
}

The World Bank

East Asia and Pacific Region

Poverty Reduction and Economic Management Sector Unit March 2001 
Policy Research Working Paper 2566

\section{Summary findings}

Much attention has been paid to the issue of possible nonlinearities in the relationship between $\log$ wages and schooling in the literature on both the United States and developing countries. Schady uses data from a recent household survey for the Philippines, the 1998 Annual Poverty Indicator Survey, to test the fit of the log-linear specification for Filipino men. He presents results based on various estimation strategies, including spline regressions and semi-parametric regressions with a large number of dummy variables for years of schooling and experience. He concludes that:

- There appear to be large differences between rates of return to education across different levels in the Philippines. The wage premia for both primary and secondary education are significantly smaller than those for tertiary education.

- Within each level--primary, secondary, and university-the last year of schooling is disproportionately rewarded in higher wages. That is, there appear to be clear sheepskin effects associated with graduation.

This paper-a product of the Poverty Reduction and Economic Management Sector Unit, East Asia and Pacific Regionis part of a larger effort in the region to understand the links between education, earnings, and welfare. Copies of the paper are available free from the World Bank, $1818 \mathrm{H}$ Street NW, Washington, DC 20433. Please contact Tania Gomez, room I8-102, telephone 202-473-2127, fax 202-522-0054, email address tgomez@worldbank.org. Policy Research Working Papers are also posted on the Web at http://econ.worldbank.org. The author may be contacted at nschady@worldbank.org. March 2001. (38 pages)

The Policy Research Working Paper Series disseminates the findings of work in progress to encourage the exchange of ideas about development issues. An objective of the series is to get the findings out quickly, even if the presentations are less than fully polished. The papers carry the names of the authors and should be cited accordingly. The findings, interpretations, and conclusions expressed in this paper are entirely those of the authors. They do not necessarily represent the view of the World Bank, its Executive Directors, or the countries they represent. 


\title{
Convexity and Sheepskin Effects in the Human Capital Earnings Function: Recent Evidence for Filipino Men
}

\author{
Norbert R. Schady ${ }^{*}$
}

\footnotetext{
*Economist, Latin America and the Caribbean Region, Poverty Reduction and Economic Management, World Bank.

${ }^{1}$ I would like to thank Harold Alderman, Jere R. Behrman, Benu Bidani, Gaurav Datt, Olivier Deschenes, Emanuela Galasso, Hans Hoogeveen, Emmanuel Jimenez, Homi Kharas, David Lam, Erzo Luttmer, Tamar Manuelyan Atinc, Peter Moock, Lant Pritchett, and Martin Rama; participants at the LACEA Conference held in Rio de Janeiro on October 12-14, 2000; and participants at a seminar held at The World Bank for many useful comments. I also thank Josie Perez and the staff of the Philippines National Statistics Office (NSO) for help with the data. Please address correspondence to the author at nschady@worldbank.org.
} 



\section{Introduction}

The relationship between education and wages is one of the most studied topics in labor economics. Since the 1970's, researchers have found a strong, positive relationship between educational attainment and wages in country after country. Most of this research has taken Mincer's (1974) formulation as a starting point. This formulation states that the log of the observed wage rate is an additive function of a linear term in years of completed schooling and a quadratic term in experience. The coefficient on the years of completed schooling is frequently referred to as the "rate of return" to education (for example Card 1999; Willis 1986). ${ }^{2}$

The log-linear relationship between wages and years of completed education has an obvious implication: Controlling for experience, every year of education, no matter at what level, adds to log earnings by the same amount. For analytical purposes, it is convenient to break down this assumption into two components. First, the log-linear specification assumes that the rate of return to education is the same across schooling levels. This assumption will not hold if the mean rate of return is higher for some levels than others-say, secondary school compared to primary school-or for some kinds of schooling —-say, university education compared to post-secondary vocational training. Such differences could be driven by a multitude of factors, including differences in the quality of education across levels, or changes in the supply of and demand for graduates

\footnotetext{
${ }^{2}$ Strictly speaking, this is only the case if a number of conditions are met (for example, if the direct private costs of education are zero, and if there is no grade repetition). These conditions are unlikely to hold perfectly in practice. In this paper I refer to the coefficient on education in the Mincerian regression as the "rate of return" for convenience, even though it would be more accurate to describe it as the "wage premium" or "wage increment".
} 
which have an effect on the price which these graduates can command in the labor market. Second, the log-linear specification assumes that the rate of return to an additional year of schooling is no higher for the last year of schooling in a particular level-primary, secondary, university — than in any other intervening year. This may not hold if credentials themselves are rewarded, a hypothesis known as the "sheepskin effect" in the literature.

The assumption of linearity in the relationship between log wages and schooling has received much attention in the United States (see, for example, Card 1999; Descienes 2000; Heckman, Layne-Farrar, and Todd 1996; Hungerford and Solon 1987; Katz and Murphy 1993; Katz and Autor 1999; Park 1994). There are also literally hundreds of empirical studies on the relationship between wages and education in Less Developed Countries (LDCs) (for reviews see Psacharopoulos 1973, 1981, 1985, 1989 and 1994). Many of these studies have attempted to identify differences in the rate of return across levels, but the data and methods used are often poor at best (see, for example, Bennell 1996 for a critique)..$^{3}$

In this paper, I use data from a recent, high-quality household survey conducted in the Philippines to test the fit of the log-linear relationship between wages and schooling. Like many middle-income countries, the Philippines has a large number of people in the labor force who have received very different amounts of schooling--ranging from no formal education whatsoever, to completed university education. This allows me to inspect the relationship between log wages and education over a broader range than

\footnotetext{
${ }^{3}$ Two studies which parametrize the earnings function in a similar way to the analysis conducted in this paper focus on Brazil (Lam and Schoeni 1993; Strauss and Thomas 1996). Both find convexity in the relationship between market wages and education, and significant, large sheepskin effects associated with the completion of particular years of schooling.
} 
would be the case in the United States. The Philippines has also seen important economic changes in the last two decades, including a supply-push to make secondary education universal, volatility in various economic indicators, including aggregate GDP growth, and substantial differences in the rate of growth of output and productivity across sectors. These changes, many of which are not yet complete, may result in differences in the rate of return to education across levels and across years which are large, at least in the short run.

The rest of the paper proceeds as follows. Section 2 gives a brief review of education and labor markets in the Philippines, including a discussion of recent literature. Section 3 describes the data set. In Section 4, I discuss the econometric specification. Section 5 presents results on the differences in rates of return across levels, and across years within levels. Section 6 concludes.

\section{Education in the Philippines}

Basic education in the Philippines is acquired in two levels: primary education (six years), and secondary education (four years). Graduates from secondary school can continue on to university (five years) or post-secondary vocational training (up to four years). ${ }^{4}$ As in most countries, there are both public and private providers of education, and the latter are particularly important at higher levels of education: Private providers of education account for a very small fraction of total enrollment in primary school (7\%), but much larger fractions for secondary school (22\%), and a majority of tertiary

\footnotetext{
${ }^{4}$ Much of this section is based on Asian Development Bank and World Bank (1999).
} 
education (77\%). Total expenditures on education in the Philippines stood at $6.9 \%$ of GDP in 1997-roughly comparable to the amount spent by other countries in a similar income bracket. The fraction of total expenditures on education which is made by private households in the Philippines (43\%) is high relative to other countries.

The Philippines has achieved impressively high enrollment rates in primary and secondary education for its income level. Administrative data indicate that the gross enrollment rate in secondary school-the fraction of children aged 13-16 enrolled in school—was 75\% in the Philippines in 1997 (Asian Development Bank and World Bank 1999, p. 158). But this high aggregate figure for the Philippines masks important differences by region: The gross enrollment ratio in secondary school in the Autonomous Region of Muslim Mindanao, for example, was only $29.7 \%$. There are also differences by gender: Analysis of the Annual Poverty Indicator Survey (APIS) shows that in rural areas $84.1 \%$ of girls aged $13-16$, but only $71.1 \%$ of boys were attending school in 1998 ; in urban areas, comparable figures were $90.4 \%$ for girls and $84.7 \%$ for boys. ${ }^{5}$

The low quality of basic education is an oft-voiced concern in the Philippines (Asian Development Bank and World Bank 2000). Poorly prepared and unmotivated teachers, inadequate teaching materials, and decaying infrastructure are all cited as problems. So is a misallocation of resources in the public system, with a very large percentage of total expenditures going to teacher salaries $(87.7 \%$ in 1999 , up from $74.3 \%$ in 1990), to the detriment of expenditures on maintenance and other operating expenditures (8.8\% in 1999, down from 16.5\% in 1990) (Asian Development Bank and World Bank 1999, 112). Filipino students perform poorly on international tests, and

\footnotetext{
${ }^{5}$ Differences by gender and region are significant at the $0.1 \%$ level or better. Similar figures, based on the 1998 Philippines Demographic and Health Survey, can be found in Filmer (1999).
} 
poorly on tests designed by the Department of Education, Culture and Sports which are intended to measure minimum acceptable levels of achievement. The quality of education provided by the private sector appears to be noticeably higher (Jimenez et. al. $1995) .^{6}$

There are numerous studies about the relationship between schooling and labor market performance in the Philippines (for example, Hossain and Psacharopolous 1994; Lanzona 1997; Maluccio 1998; Tan and Paqueo 1989). None of these studies focus on the issue of possible non-linearities in the earnings function per se, and those which use national-level data are by now outdated. The Lanzona (1997) and Maluccio (1998) papers are based on a panel of households interviewed in 1978, 1983, and 1994. Because the households selected are all in a single province of the 78 which exist in the Philippines (the province of Camarines Sur, in the Bicol region), it is not clear whether the results in these papers are applicable to the country at large.

\section{The data set}

This paper is largely based on the 1998 Annual Poverty Indicator Survey (APIS). The APIS covered 38,710 households, including 195,791 individuals. It is the first nationwide multipurpose survey conducted in the Philippines, and includes a basic consumption and income module, as well as modules addressing the educational

\footnotetext{
${ }^{6}$ The low quality of education may be one of the factors contributing to the poor economic performance of the Philippines. Since 1984, real GDP per capita has essentially been stagnant: The total change in real GDP per capita between 1984 and 1999 was $2.6 \%$, a very small amount indeed in comparison with many of the Philippines' East Asian neighbors, which posted annual growth rates above 5\% for much of the period. Productivity in the Philippines declined for the economy as a whole (by about $0.9 \%$ over the fifteen-year period), and fell dramatically in industry (declining by $17.0 \%$ during the period).
} 
attainment, health status, and degree of contraceptive use by various household members.

Exceptionally, the 1998 APIS also included a module intended to capture the householdlevel effects of the dual financial and El Nino crises in the Philippines in 1998 (see Datt and Hoogeveen 2000). ${ }^{7}$

The wage module in the APIS is quite detailed. It asks all household members aged 5 and older about salaries and wages earned in two three-month periods prior to the survey (April 1 to June 30, and July 1 to September 30). Data is gathered separately for the "primary" job and "others". The value of "basic salaries and wages, in cash or in kind" is recorded separately from the value of "allowances, honoraria, tips, housing, clothing, food, etc., in cash or in kind" (separately for both jobs, where applicable). In addition, the survey asks about the number of full days worked, the average number of working hours in these full days, the number of less-than-full days worked, and the average number of hours worked in these less-than-full days (again, separately for both jobs, where applicable). Information on the number of hours and days is collected separately for the months of July, August, and September (but no information on days or hours is collected for April through June). Like most surveys of its kind, the APIS also includes questions about the sector of employment, business classification, and class of worker for those employed. Finally, all adults who have not held a job at all in the six months prior to the survey are asked if they have been looking for work and, if they have not, why.

\footnotetext{
${ }^{7}$ About $60 \%$ of the households in the 1998 APIS are part of a panel with a survey carried out in 1997, the Family Income and Expenditure Survey (FIES). The FIES, which has been conducted in three-year intervals since 1985, has important advantages over the APIS-most notably, the fact that the consumption and income modules are much more extensive. But the FIES is not truly a multi-purpose survey. It includes information only on very basic household demographics and, for example, no information on the educational attainment of household members other than the household head. The large difference in the
} 
I construct mean hourly wages for the three-month period prior to the survey by adding the "wage" and "allowance" components for the main job, and dividing this by the total number of hours worked. All wages are deflated with provincial-level price deflators - one for each of the 73 provinces in the country, as well as, separately, the 11 biggest cities (Balisacan 2000). I consider only men working in the wage-earning sector, rather than all employed men. ${ }^{8}$ This is because very few self-employed men report "wages", and it is not clear what to make of the wage data for those who report being self-employed and earning wages on the same job. For similar reasons, the analysis in this paper is limited to the main job, because some men whose main job is in the wageearning sector have a second job where they are self-employed. ${ }^{9}$ The education module in the APIS is also reasonably detailed. For the purposes of this paper, the relevant question asks about the highest grade completed by all household members aged 6 and older. With the exception of those currently enrolled in school, the APIS provides no information about the kind of school attended by labor force participants, including whether it was public or private.

There are 21,882 men in the APIS who report all of the necessary information for the construction of hourly wages, including data on wages, allowances, days and hours worked on the main job, as well as information on own schooling. In addition, we can

length of the consumption and income modules in the APIS and the FIES means that it is not possible to compare changes in income or consumption in any straightforward way.

${ }^{8}$ The APIS gives seven categories for class of worker: (i) worked for private household; (ii) worked for private establishment; (iii) worked for government / government corporation; (iv) self employed without any employee; (v) employer in own family operated farm or business; (vi) worked with pay on own familyoperated farm or business; (vii) worked without pay on own family-operated farm or business. The analysis in this paper is restricted to categories (i), (ii), (iii), and (vi) above.

${ }^{9}$ Note, however, that only a tiny fraction $(0.34 \%)$ of men in the sample who hold a wage-earning main job report holding a second wage-earning job, so restricting the analysis to the main job is unlikely to make much of a difference. 
construct measures of parental education, and a measure of male sibling education for two sub-samples (corresponding to 2,355 , and 2,851 men, respectively). These subsamples can be useful to help control for various biases - in particular, possible biases induced by the correlation between unobserved ability, own schooling, and selection into the wage-earning sector-but they have important limitations, both because of their much smaller size, and because they are arguably non-random: Information on parental education is only available for wage-earning children of the household head in households in which both parents are still present, while information on the education and earnings of male siblings is only available for children of the household head in households with at least two male children, both of whom are living at home, and both of whom earn wages. As a result, these samples will tend to be younger, and may be biased if formation of an independent household is endogenous.

\section{Estimation strategy}

The analysis in this paper is limited to men only. This is somewhat arbitrary, although the much larger sample size for wage-earning men $(21,882)$ than women $(11,228)$ in the APIS is an important advantage. In addition, limiting the sample to men may minimize two econometric problems. First, it is likely that non-random selection into the labor market is more of a concern for women than for men. Second, like most household surveys, the APIS did not collect information on labor market experience, so I approximate actual experience with "potential experience", defined as $\mathrm{X} \equiv \mathrm{A}-\mathrm{S}-6$, where A stands for age in years, and $\mathrm{S}$ is the years of completed schooling. This 
formulation, which is standard in the literature, assumes that all children start schooling at age 6 and complete $S$ years of schooling in exactly $S$ years, and begin accumulating labor market experience as soon as they leave school. "Potential experience" could seriously over-estimate the number of years of experience of women if women who are currently in the labor market have taken time out at an earlier point in their career to raise children (for example, Altonji and Blank 1999). ${ }^{10}$ Finally, because of the very small number of observations, I exclude from the sample men whose highest degree is postsecondary vocational training or post-college education (Master's or Ph.D.).

To estimate the degree of convexity in the earnings function, and to capture any possible sheepskin effects, I use spline functions and semi-parametric regressions. A discontinuous spline function, proposed by Hungerford and Solon (1987), and which has since formed the basis for much of the literature on "sheepskin effects" in the United States, can be specified as follows:

(1) $\quad \log \mathrm{W}_{i}=\alpha+\chi \mathrm{X}_{i}+\delta \mathrm{X}^{2}{ }_{i}+\beta \mathrm{S}_{i}+\eta \mathrm{D} 6_{i}+\theta\left[\left(\mathrm{S}_{i}-6\right)^{*} \mathrm{D} 6_{i}\right]+\gamma \mathrm{D} 10_{i}+\lambda\left[\left(\mathrm{S}_{i}-10\right)^{*} \mathrm{D} 10_{i}\right]+$ $\zeta_{\mathrm{D}} 15_{i}+\mathrm{v}_{i}$

where $S$ and $X$ are the years of completed schooling and potential experience, D6, D10, and D15 are dummy variables for those who have completed at least six, ten, and fifteen years of schooling, respectively, $\left[\left(\mathrm{S}_{i}-6\right)^{*} \mathrm{D} 6_{i}\right]$ is an interaction term between the D6

\footnotetext{
${ }^{10}$ The use of "potential experience" rather than actual experience may also introduce biases in the estimation of the effects of experience on earnings-for example, if children start school late, or if repetition rates are anything other than zero. "Potential experience" will then tend to overstate actual experience, and the coefficient on experience may be a (downward) biased estimate of the returns to actual experience.
} 
dummy and $\mathrm{S}-6,\left[\left(\mathrm{~S}_{i}-10\right)^{*} \mathrm{D} 10_{i}\right]$ is an interaction term between the D10 dummy and $\mathrm{S}-10$, and $v_{i}$ is the error term in the regression. In this piece-wise linear specification, the mean rate of return to the first five years of education is given by the parameter $\beta$; the rate of return to the sixth year of education is given by the sum of the parameters $\beta$ and $\eta$; the mean rate of return to the first three years of secondary schooling is given by the sum of the parameters $\beta$ and $\theta$; the rate of return to the last year of secondary school is given by the sum of the parameters $\beta, \theta$, and $\gamma$; the mean rate of return to the first four years of university is given by the sum of the parameters $\beta, \theta$, and $\lambda$; while the rate of return to the last year of university is given by the sum of $\beta, \theta, \lambda$, and $\zeta$. An alternative, which suppresses the three dummy variables (but not the interaction terms), gives the mean rate of return to education by level.

One concerr. with this estimation framework is the possible effect of individual heterogeneity. Card (1999) generalizes the discussion of "ability bias" in earnings functions by showing that heterogeneity can have an effect on both the intercept and the slope of a given individual's earnings function. Either one of these conditions is enough to upward-bias the coefficient on schooling in a cross-sectional earnings regression but a positive correlation between schooling and the marginal return to schooling can also result in an estimated convex relationship in a cross-sectional regression of log earnings on schooling-even in the absence of any convexity in the underlying individual earnings functions.

To partially control for ability, I run two additional sets of regressions. First, I limit the sample to men for whom we have data on parental education, and include the years of completed schooling of both parents as controls. Second, I limit the sample to men for 
whom we have data on the education and earnings of male siblings, and use "within"

estimators which include the total education of all wage-earning male siblings as a

control (see Card 1999 for a general discussion, and Heckman and Hotz 1986, and Lam

and Schoeni 1993 for applications in LDC settings). An additional advantage of these

regressions is that including partial controls for ability should reduce the biases

associated with non-random selection into the wage-earning sector if this selection is

itself partly determined by ability. ${ }^{11}$

I also consider two semi-parametric regression models. In the first, experience and

squared experience are still assumed to have an additive effect on log wages, but

education is captured by fifteen schooling dummies:

(2) $\log \mathrm{W}_{i}=\alpha+\eta_{x} S_{i}+\theta \mathrm{X}_{\mathrm{i}}+\lambda \mathrm{X}^{2}{ }_{\mathrm{i}}+\varepsilon_{i}$,

This imposes fewer restrictions than a spline function (see also Hungerford and Solon

1987; Lam and Schoeni 1993; Strauss and Thomas 1996). Here, too, I estimate the

"bare-bones" semi-parametric regression, as well as regressions which include parental

\footnotetext{
${ }^{11}$ An alternative would have been to correct explicitly for selection with the correction proposed by Heckman (1976). In separate results (not reported, but available from the author upon request), I compare OLS estimates with estimates from a Heckman selection model, in which education of the spouse is used as an identifying variable for a sub-sample of married men in the APIS. The selection-corrected estimates are very similar to the simple OLS estimates: In the full sample of married men, for example, the coefficient on own schooling is .122 in the OLS regression, and .128 in the selection-corrected regression. These estimates assume that spousal education helps determine participation in the wage-earning sector, through its effect on household income, but does not have an independent effect on own productivity and wages. This seems plausible, but assortative mating between husbands and wives in terms of unobserved ability may cast some doubts on this identification strategy (for a discussion, see Behrman, Birdsall, and Deolalikar 1995; Behrman, Rosenzweig, and Taubman 1994; and Lam and Schoeni 1993). Another oftused candidate for identification, the amount of non-wage household income, including public transfers, pensions, interest and dividends, is not a significant predictor of participation in the labor market conditional on age and education in the APIS sample. Note, finally, that as is well-known, the Heckmancorrected estimates assume homoskedasticity and joint normality in the residuals from the swithching and wage regressions.
} 
education as a control, and within-sibling estimates. Finally, I estimate a very flexible regression model in which the log of the individual wage rate is regressed on a set of 15 schooling dummies, 10 experience dummies, and 150 interactions between experience and schooling:

(3) $\log \mathrm{W}_{i s x}=\eta_{x} \mathrm{~S}_{i s}+\theta_{s} \mathrm{X}_{i x}+\lambda_{s x}\left(\mathrm{~S}_{i e} * \mathrm{X}_{i x}\right)+v_{i s x}$,

where the subscripts $\mathrm{i}, \mathrm{s}$, and $\mathrm{x}$ stand for individuals, years of schooling, and experience cohort. ${ }^{12}$ An important appeal of this approach is that it allows the effect of education on wages to vary by experience (see Card 1999, pp. 1805-06). An obvious limitation is that this estimation strategy will produce noisy estimates in the absence of very large sample sizes.

\section{Results}

I present summary statistics on the sample of wage-earning men in the APIS in Table 1, non-parametric density estimates of the logarithm of the wage distribution in Figure 1, and histograms for the years of completed schooling in Figure 2. These results are weighted by the appropriate expansion factors, and are presented for four groups: All men who report earning wages, men aged $25-65$, the sub-sample of men for whom we

\footnotetext{
${ }^{12}$ Years of experience have been lumped together into five-year groups, such that the first group (experience $=1$ ) corresponds to workers with 0 to 5 years of experience, the second group (experience $=2$ ) corresponds to workers with 6 to 10 years of experience, and so on. I do this to avoid the very small sample sizes which would have resulted had I created dummy variables for every year of experience. This model therefore estimates 160 coefficients (fifteen dummy variables have to be dropped to avoid perfect colinearity).
} 
have information on the number of years of completed schooling of both parents, and the sub-sample of men for whom we have information on education and earnings for themselves as well as at least one male sibling. Table 1 shows that men in these last two categories tend to be much younger: The mean age is 33 for all wage-earning men, 38 for men aged 25 to 65,22 for men for whom information on parental education is available, and 23 years for the sample of male siblings. Figure 1 shows that the distribution of log wages is approximately normal for all four groups, with means at 2.71 (all men), 2.86 (men aged 25 to 65), 2.36 (men with data on parental education), and 2.39 (men with data on male siblings). The lower mean wages of the younger men are, presumably, a result of less years of labor market experience, as well as of the fact that these younger men have slightly less education ( 8.5 years and 8.12 years, respectively, rather than 8.8 years for all wage-earning men in the sample, or 9.1 years for men aged 25 to 65). Figure 2 shows that these means hide important spikes in the distribution. In the full sample, for example, $19.9 \%$ of the men have completed exactly six years of education, $25.5 \%$ have completed exactly ten years, and $12.5 \%$ have completed exactly fifteen years, corresponding to completion of primary school, secondary school, and university, respectively (histograms for the other three samples are very similar, and are available from the author upon request).

Tables 2 presents the results from estimating the spline function models for the sample of Filipino men in the APIS. I present six sets of results, corresponding to specifications for all males reporting wage earnings, with and without provincial dummies (columns 1 and 2), and for the smaller sample of men aged 25 to 65 (column 3). Results for the full model, including the years-of-education dummy variables, are 
reported in the upper panel of the table, while results without these dummies are reported in the lower panel.

A number of things are worth noting about the results in Table 2. First, a joint Ftest shows that the more flexible spline function is a significant improvement in fit over the prototypical Mincerian equation in all of the specifications. Second, the mean wage premium appears to vary considerably by level. The continuous spline specification for the full sample of men, for example, indicates that this premium is smallest for primary education (.094), slightly larger for secondary education (.100), although the increase is not significant, and much larger for tertiary education (.167), a change in slope which is significant at any conventional level. This would suggest considerable convexity in the relationship between the wage rate and years of completed schooling. Third, there appear to be large, significant sheepskin effects, especially at the university level. In the full sample, these range from .121 for primary school, to .129 for secondary school, to a whopping .276 for university. Note that these estimated sheepskin effects may be biased down if some individuals do not earn degrees even if they have completed the required number of years of schooling, and others earn degrees even if they have not completed exactly 6,10 , or 15 years of schooling. ${ }^{13}$ Adding provincial dummies to the regressions increases the difference between the mean wage premium associated with an additional year of primary school (.062) and a year of university (.171), and greatly reduces the sheepskin effects at the primary and secondary levels (but not university).

The results based on the semi-parametric regressions in equation (2), presented in Table 3 and Figure 4, are quite consistent with those reported in Table 2. These estimates 
show clear differences between the mean (unweighted) step size for primary school (.089) and university (.167); a flattening of the earnings function at the primary and secondary levels when provincial dummies are included; and very large sheepskin effects associated with graduation from university.

Tables 4 and 5, finally, present the results which include parental education as controls (columns 1 and 2), and the within-sibling estimates (columns 3 and 4). Differences between these results and those in Tables 2 and 3 could be caused by inclusion of the additional controls, as well as by differences in the sample. In order to hold constant the effect of differences in the sample, I therefore present results for the smaller samples both with and without the additional controls. These results show, first, that the education of both parents has a significant, positive impact on log wages, with the effect of father's education being noticeably (and significantly) larger. ${ }^{14}$ Second, all of the coefficients on own schooling are smaller in these specifications which attempt to control for ability. The coefficient on primary education, for example, drops from .094 to .078 when parental education is included as a control, and from .103 to .086 in the within-sibling regression. Similarly, the coefficient on university education drops from .196 to .162 in the regression which includes parental education, and from .176 to .158 in the within-sibling regression. Third, the estimated sheepskin effects are quite robust to the inclusion of controls for parental education. However, there appears to be something peculiar in the sample of men with wage-earning siblings: The coefficient on the

\footnotetext{
${ }^{13}$ Jaeger and Page (1996), for example, find much larger sheepskin effects than those reported by Hungerford and Solon (1987) when they use information on both years of schooling and actual degree awarded for a sample of workers in the United States.

${ }^{14}$ Contrast this with the results in Heckman and Hotz (1986), who find that mother's schooling has a larger impact than father's schooling on wages for a sample of Panamanian men.
} 
university graduation effect is greatly reduced in size and becomes insignificant in this sample, both when siblings' education is included as a control, and when it is not, while the coefficient on the all-but-last year of schooling in the semi-parametric regression is very large (.476 to .585$)$, and significant at the $10 \%$ level or better.

What explains the convexity of the earnings function for Filipino men? I consider three possible explanations: Heterogeneity bias associated with ability, a supply-demand mismatch, and differences in the quality of education received at different levels.

Individual heterogeneity can lead both to an upward-biased estimate of the effect of schooling on earnings, as well as to the appearance of convexity in a cross-sectional regression in the absence of convexity in the underlying earnings functions. The results in Tables 4 and 5 show that the coefficients on own schooling are indeed smaller in the regressions which include controls for parental education, as well as in the within-sibling regressions, but the ratio of the university-to-primary-school coefficients-a measure of the degree of convexity in the earnings function-is virtually unchanged. The fact that the estimated convexity is unchanged suggests either that these supplemental regressions do a poor job controlling for heterogeneity bias in the slope of the earnings function, or that heterogeneity is not the main reason for convexity in this sample of Filipino men. ${ }^{15}$

An alternative explanation for the estimated convexity is that the high rates of return to tertiary education are the result of differences in the relative demand for and supply of workers with different amounts of education. Some support for this idea is

\footnotetext{
${ }^{15}$ One limitation of these regressions is that it is not clear ex ante whether these partial controls for ability should minimize differences in the intercept or the slope of the earnings function across individuals. This is unfortunate, as only differences in the underlying slopes lead to (estimated) convexity in cross-sectional regressions. A second limitation is that both approaches-controlling for parental education, and withinsibling estimates-reduce the signal-to-noise ratio, and will therefore tend to aggravate measurement error in own schooling (for example, Griliches 1977; Lam and Schoeni 1993).
} 
given by gross enrollment figures for the Philippines: Between 1980 and 1997, gross

enrollment ratios increased in primary school (by $4.4 \%$, from 113 to 118 ) and secondary

school (by 15.4\%, from 65 to 75 ), and decreased at the tertiary level (by $19.2 \%$, from 26

to 21) (Asian Development Bank and World Bank 1999, p. 149). ${ }^{16}$ Moreover, these

changes in supply took place at a time when, if anything, there appears to have been an

increase in the demand for more skilled workers in the Philippines-for example, in the

booming electronics sector. ${ }^{17}$

Finally, there may be large differences in quality across education levels in the

Philippines, with higher quality education being provided in university (for a general

discussion of this issue see Strauss and Thomas 1995, pp. 1971-72, as well as Behrman

and Birdsall 1983). If there are indeed quality differentials, these could be related to a

quality-diluting expansion in primary and secondary enrollments. Whether the fact that a

higher fraction of university education than primary or secondary education is provided

\footnotetext{
${ }^{16}$ However, gross enrollment rates at the tertiary level in the Philippines were well above those of its neighbors throughout the 1990's, including Thailand, China, Indonesia, and Malaysia (but not Korea) (World Development Indicators database, The World Bank). There is also some discrepancy between these figures and those in the World Development Indicators database, which actually show an increasing enrollment ratio for tertiary education in the Philippines over the 1990's. The difference between these estimates appears to be that the World Development Indicators include enrollment in non-university tertiary institutions, whereas the Asian Development Bank and World Bank (1999) report do not. Alternatively, I could have used data on educational attainment (rather than enrollment), such as those found in Barro and Lee (1993) or Nehru, Swanson and Dubey (1994), for the comparisons in this paper. These data sets have been criticized on numerous grounds (Behrman and Rosenzweig 1994). For the purposes of my analysis, the main disadvantage of these data sets is that they do not provide post-1987 data. See also Pritchett (1996).

${ }^{17}$ Disaggregated data on sector of employment, which was collected in the APIS but was not available for this paper, might help clarify this point by showing whether there were large differences in wage premia across sectors. Pritchett (1996), for example, argues that the rate of return to education is generally highest in sectors in which there is exogenous technological progress. Amongst other evidence, he cites work by Foster and Rosenzweig (1996) on India, which suggests that rates of return to education went up in villages where the Green Revolution brought agricultural innovation, but not in technologically-stable villages.
} 
by the private sector also has implications for quality is a matter of conjecture, although Jimenez et. al. (1995) argue that this is plausible. ${ }^{18}$

What accounts for the very large sheepskin effects found in the Philippines? Here, too, I discuss three possibilities: Credentialism, differences in the actual amount of learning acquired by students who complete the last year within a given level, rather than any intervening year, and discontinuities in ability associated with discontinuities in the cost of education across levels.

Credentialism and signaling are the most-frequently cited explanations in the literature for the presence of measured sheepskin effects in the United States. Referring to the original Hungerford and Solon (1987) article, Belman and Heywood (1991, p. 720) write that "the finding that a diploma had value independent from the accumulated years of education indicated that in addition to any role it plays actually making workers more productive, education also credentiates workers as more productive". In the Philippines, where information in the labor market is likely to be far less accurate than in the United States, credentialism of this sort may be even more important. One reasonable question might be what kinds of employers reward credentials. Separate estimation of discontinuous spline functions for government and private sector employees for the full sample of men show a university graduation effect that is more than twice as large in the private sector (.343, significant at the $0.1 \%$ level) as in the public sector $(.153$, significant at the 5\% level). This is similar to the pattern found in the United States (Heywood 1994), but different from that found in some African countries, where sheepskin effects

\footnotetext{
${ }^{18}$ Moreover, a large fraction of students currently attending university in the Philippines are enrolled in technical subjects, such as engineering, which are likely to be associated with high rates of return (World Bank 2000, pp. 15-16).
} 
appear to be larger in the public sector than in the private sector (on Ghana, see Glewwe 1996, who also cites similar results for Kenya and Tanzania in Boissiere et. al. 1985).

A second explanation for the sheepskin effects may be that there are differences in the "difficulty" of years within a given level, and therefore in the amount of learning which actually takes place. For example, if there are more rigorous exams at the end of the last year within a cycle, completing this last year may lead to a greater marginal increase in human capital than completing any other intervening year, and may therefore be rewarded disproportionately by rational employers in the labor market. There is some anecdotal evidence in the Philippines that passing the last year within a given cycle may be more difficult than passing preceding years, especially at the university level.

Finally, there may be sharp discontinuities in ability in the transition years between education cycles. ${ }^{19}$ In the Philippines there appear to be very large differences in the direct private costs of education across levels. Table 6 shows that the private unit costs of education increase steeply by level: The mean unit cost of primary education is 898 pesos, while the mean unit cost of tertiary education is 13,334 pesos-almost $10 \%$ of mean household consumption. There are even larger differences in the unit costs for a given education level by per capita consumption quintile: The richest households spend more than 20 times as much as the poorest households for every child in primary school, and more than 10 times as much for every child in university. ${ }^{20}$ To see how these

\footnotetext{
${ }^{19}$ I thank Jere R. Behrman for this suggestion.

${ }^{20}$ I would particularly like to thank Hans Hoogeven for help with this calculation. Disaggregated data on the private costs of education per household are available in the 1997 Family Income and Expenditure Survey (FIES), but not in the 1998 APIS, while data on household composition, including the number of children attending different education levels are available in the APIS, but not in the FIES. I use the panel of households included in both the FIES and APIS to estimate the private unit cost of primary, secondary, and tertiary education by running an auxiliary regression of the total amount spent by a household on education in 1997 on the number of children attending each education level in 1998: $\mathrm{Ex}_{h}=\beta \mathrm{P}_{h}+\gamma \mathrm{S}_{h}+\delta \mathrm{T}_{h}$ $+\varepsilon_{h}$, where Ex is the total amount spent by household $h$ on education in 1997, P, S, and T are the total
} 
discontinuities in costs could interact with the distribution of ability, consider the simplest of examples—one in which there are three populations, a "poor" population, which can only afford primary schooling, a "medium" population, which can afford primary and secondary schooling (but not university), and a "rich" population, which can afford primary, secondary, and tertiary schooling. Figure 5 shows a hypothetical example in which ability is assumed to rise with years of schooling, and to reach the same maximum for those students who are attending the highest year of schooling they can afford. In this example, discontinuities in costs, which result in a cut-off in the amount of schooling which different populations can afford, lead to discontinuities in the distribution of aggregate ability (the heavy line in the graph) - where aggregate ability is simply the weighted average of the ability of "poor", "medium", and "rich" students for a given year of schooling. If unobserved ability is rewarded in the labor market, as seems likely, then the discontinuities in ability could result in discontinuities in the earnings function. Note, however, that the hypothetical distribution of ability in Figure 5 would lead to inordinately "low" earnings for those with only the first year(s) of secondary

number of children in household $\mathrm{h}$ who are attending primary school, secondary school, and university in 1998 , and the constant in the regression has been suppressed. The parameters $\beta, \gamma$, and $\delta$ will provide a reasonable approximation to the private unit costs, by level, if attendance rates in 1998 are close to those in 1997. This procedure assumes that household composition, the fraction of children who are attending school at every level, and actual (rather than measured) unit costs remained constant between 1997 and 1998. There is no reason to suppose that household composition or unit costs changed in the Philippines between 1997 and 1998. Attendance rates may have dropped, however, because of the effect of the East Asian crisis on incomes in 1998, even though the Philippines was much less affected by the crisis than other countries in the region. Administrative data show no significant impact of the crisis on enrollment rates in primary or secondary school; but attendance rates may still have fallen if households were more likely to keep their children at home or doing odd jobs. A weaker assumption for the calculation of unit costs is that attendance rates in primary school, secondary school, and university in 1998 are a constant fraction of attendance rates in 1997, such that $\mathrm{E}_{\mathrm{p}}{ }^{98}=\psi \mathrm{E}_{\mathrm{p}}{ }^{97}, \mathrm{E}_{\mathrm{s}}^{98}=\psi \mathrm{E}_{\mathrm{s}}^{97}$, and $\mathrm{E}_{\mathrm{c}}^{98}=\psi \mathrm{E}_{\mathrm{c}}{ }^{97}$, where the subscripts stand for education levels, superscripts for years, and the parameter $\psi$ is less than one. Under this assumption, the proposed estimation procedure will over-estimate unit costs by a factor $1 / \psi$, but will produce accurate estimates of the ratio of unit costs across levels. 
school or university, rather than to inordinately "high" earnings for those who have completed exactly the last year of schooling within a given level.

Two other features of the estimated sheepskin effects in the Philippines are worth noting. First, Tables 3 and 5, and Figure 3 all show that the estimated sheepskin effects in the Philippines do not appear to be the result of a particularly small increase in earnings for those who have all-but-the-last year of schooling within a given level (that is, people with 5,9 , or 14 years of education), something which has been argued for the United States (Park 1994). ${ }^{21}$ Second, there is no evidence that sheepskin effects diminish with experience in the Philippines. In Figure 4, I present results based on an estimation of equation (3) above for the full sample of men. Each point on a graph corresponds to the expected earnings for a given combination of education and experience, while the vertical lines correspond to six years of education (completed primary) and ten years of education (completed secondary). The results, which can be quite noisy because of the small sample sizes in some cells, show no clear pattern in the relationship between sheepskin effects and experience: The wage premia associated with completion of the last year of university are $.504, .374, .387, .213, .355, .488, .180, .240,-.010$, and 1.083 for the first through tenth experience cohorts. ${ }^{22}$

\footnotetext{
${ }^{21}$ As noted above, the results based on the sample of male siblings are particularly confusing because the largest wage premium is associated with the all-but-last year of university.

${ }^{22}$ Belman and Heywood (1997) suggest that sheepskin effects in the United States appear to become attenuated with experience, although there is no clear evidence of such attenuation in the results presented by Heckman, Layne-Farrar, and Todd (1996, pp. 585-89) using the 1970, 1980, and 1990 US Censuses. Another way of estimating the effect of experience on credentials, suggested to me by Harold Alderman, would interact the dummy variables D6, D10, and D15 in the discontinuous spline specification with experience. The results from such an estimation strategy show that the coefficients on these interactions tend to be significantly negative for graduation from primary school and secondary school, and significantly positive for graduation from university. Note that the experience variable, as constructed, is simply a function of age and education. Unfortunately, the 1998 APIS does not include questions about the amount of time a worker has spent in his current job, which might be more relevant for these calculations.
} 
Note, finally, that it is impossible to disentangle age, cohort, and year effects with a single cross-section of data. Consider, for example, the ratio of the slopes of the earnings function for workers with university education relative to workers with primary education. This ratio appears to be noticeably larger in the graphs in the second panel of Figure 4 than those in the first panel. This difference in the relative slopes could be the result of an improvement in the quality of primary school which has affected recent labor market entrants-a cohort effect—or the fact that the relatively low returns to primary school only bite later on in a worker's life- an age effect. ${ }^{23}$

\section{Conclusion}

There is considerable evidence which suggests an increase in the mean rate of return to education over time, increasing convexity in the earnings function, and large, significant sheepskin effects in education in the United States. Similar work on LDC's is still far from the norm-even though the supply-demand mismatches, and the poor information flows in the labor market which are (some of the possible) explanations for non-linearities in the earnings function are likely to be much more serious problems in these countries than in the United States.

This paper adds to the literature by exploiting a recently-available, high-quality data set, the 1998 Philippines APIS survey. I show that there are large differences in the wage premia across education levels, and very large, significant sheepskin effects

\footnotetext{
${ }^{23}$ Farber and Gibbons (1996) present recent evidence for the United States which suggests that the effect of education on log wages diminishes with experience, although it is not clear how the relative earnings of workers with different amounts of education change with experience.
} 
associated with completion of the last year within a level for Filipino men. The results are reasonably robust to partial controls for ability, such as inclusion of measures of parental education, and within-sibling estimates. These findings have important possible implications for the decisions taken by private individuals as well as governments. For example, at reasonable discount rates, a very high degree of convexity in the earnings function could make further education unattractive for all but those who expect to complete the highest years of schooling. ${ }^{24}$

Returns to education are not static, in the Philippines or elsewhere, and the shape of the earnings function may well change over time. ${ }^{25}$ Additional research on a developing country with numerous cross-sections of data would allow for distinctions to be made between the age, cohort, and year effects which underlie changes in the relative shape of the earnings function.

\footnotetext{
${ }^{24}$ One puzzling question which this paper does not address is how the high education levels and the reasonably high overall returns to education are consistent with the declining productivity and very low levels of growth found in the Philippines in the last two decades (for a general discussion, see Pritchett 1996).

${ }^{25}$ Indeed, because 1998 was a year in which the Philippine economy was affected by the East Asian crisis, it might not be a representative year to study the relationship between wages and education-even though the effects of the crisis were nowhere near in magnitude to those felt by many of the Philippines' neighbors: The year-on-year change in real GDP per capita for the third quarter of 1998 , corresponding to the period for the wage data in our sample, was only $-2.2 \%$.
} 


\section{Bibliography}

Altonji, Joseph G. and Rebecca Blank. 1999. "Race and Gender in the Labor Market”, in Orley Ashenfelter and David Card, eds., Handbook of Labor Economics, Volume 3C, 3143-3259, Amsterdam, Elsevier.

Asian Development Bank and World Bank. 1999. Philippine Education for the $21^{\text {st }}$ Century: The 1998 Philippines Education Sector Study, Manila, Asian Development Bank.

Balisacan, Arsenio. 2000. "Growth, Inequality, and Poverty Reduction in the Philippines; A Re-examination of Evidence", mimeo, University of the Philippines.

Barro, Robert, and Jong-Wa Lee. 1993. "International Comparisons of Educational Attainment”, Journal of Monetary Economics 32, No. 3, pp. 363-94.

Behrman, Jere R., and Nancy Birdsall. 1983. "The Quality of Schooling: Quantity Alone is Misleading", American Economic Review 73, No. 5, pp. 928-46.

Behrman, Jere R., and Mark Rosenzweig. 1994. "Caveat Emptor: Cross Country Data on Education and the Labor Force", Journal of Development Economics 44 (June), pp. 147 71.

Behrman, Jere R., Nancy Birdsall and Anil B. Deolalikar. 1995. "Marriage Markets, Labor Markets, and Unobserved Human Capital: An Empirical Exploration for SouthCentral India", Economic Development and Cultural Change 43, No. 3 (April), 585-602.

Behrman, Jere R., Mark R. Rosenzweig, and Paul Taubman. 1994. "Endowments and the Allocation of Schooling in the Family and in the Marriage Market: The Twins Experiment", Journal of Political Economy 102, No. 6 (December), 1131-74.

Belman, Dale, and John S. Heywood. 1997. "Sheepskin Effects by Cohort: Implications of Job Matching in a Signaling Model", Oxford Economic Papers 49, 623-37.

Bennell, Paul. 1996. "Rates of return to Education: Does the Conventional Pattern Frevail in sub-Saharan Africa?", World Development 24, No. 1, 183-99.

Boissiere, M., J.B. Knight, and R.H. Sabot. 1985. "Earnings, Schooling, Ability, and Cognitive Skills", American Economic Review 75, No. 5, 1016-30.

Card, David. 1999. "The Causal Effect of Education on Earnings", in Orley Ashenfelter and David Card, eds., Handbook of Labor Economics, Volume 3A, 1800-1863, Amsterdam, Elsevier. 
Datt, Gaurav, and Hans Hoogeveen. 2000. "El Niño or El Peso? Crisis, Poverty and Income Distribution in the Philippines" World Bank Policy Research Working Paper 2466.

Deschenes, Olivier. 2000. "Unobserved Ability, Comparative Advantage and the Rising Return to Education in the United States: A Cohort-Based Approach", processed, Princeton Univeristy.

Farber, Henry S., and Robbert Gibbons. 1996. "Learning and Wage Dynamics", Quarterly Journal of Economics 111, No. 4, 1007-47.

Filmer, Deon. 1999. "The Effect of Household Wealth on Educational Attainment: Evidence from 35 Countries", Population and Development Review 25, No. 1, 85-120.

Foster, Andrew and Mark R. Rosenzweig. 1996. "Technical Change and Human Capital Returns and Investments: Evidence from the Green Revolution", American Economic Review 86, No. 4, pp. 931-53.

Glewwe, Paul. 1996. "The Relevance of Standard Estimates of Rates of Return to Schooling for Education Policy: A Critical Assessment", Journal of Development Economics 51, 267-90.

Griliches, Zvi. 1977. "Estimating the Returns to Schooling: Some Econometric Problems", Econometrica 45, No. 1, pp. 1-22.

Heckman, James. 1976. "The Common Structure of Statistical Models of Truncation, Sample Selection and Limited Dependent Variables and a Simple Estimator for Such Models", Annals of Economic and Social Measurement 5, No. 4, 475-92.

Heckman, James, Anne Layne-Farrar and Petra Todd. 1996. "Human Capital Pricing Equations with an Application to Estimating the Effect of Schooling Quality on Earnings", Review of Economics and Statistics 78, No. 4, 562-610.

Heckman, James, and V. Joseph Hotz. 1986. "An Investigation of the Labor Market Earnings of Panamanian Males: Evaluating the Sources of Inequality", Journal of Human Resources 21, No. 4, pp. 507-42.

Heywood, John S. 1994. "How Widespread are Sheepskin Returns to Education in the US?", Economics of Education Review 13, 227-34.

Hossain, Shaikh I., and George Psacharopoulos. 1994. "The Profitability of School Investments in an Educationally Advanced Developing Country", International Journal of Educational Development 14, No. 1, 35-42.

Hungerford, Thomas, and Gary Solon. 1987. "Sheepskin Effects in the Returns to Education", Review of Economics and Statistics 69, No. 1, 175-77. 
International Monetary Fund. International Financial Statistics, various years.

Jaeger, David A., and Marianne E. Page. 1996. "Degrees Matter: New Evidence on Sheepskin Effects in the Returns to Education", Review of Economics and Statistics 77, No. 4, 733-39.

Jimenez, Emmanuel and Marlaine Lockheed with contributions from Donald Cox. 1995. Public and Private Secondary Education in Developing Countries: A Comparative Study, Washington, D.C., The World Bank.

Katz, Lawrence F., and Kevin M. Murphy. 1992. "Changes in Relative Wages, 19631987: Supply and Demand Factors", Quarterly Journal of Economics 107, No. 1, 35-78.

Katz, Lawrence F., and David Autor (1999). "Changes in the Wage Structure and Earnings Inequality", in Orley Ashenfelter and David Card, eds., Handbook of Labor Economics, Volume 3A, Amsterdam, Elsevier.

Lam, David, and Robert F. Schoeni. 1993. "Effects of Family Background on Earnings and Returns to Schooling: Evidence from Brazil", Journal of Political Economy 101, No. 4, pp. 710-40.

Lanzona, Leonardo A. 1998. "Migration, Self-Selection and Earnings in Philippine Rural Communities", Journal of Development Economics 56, No. 1, 27-50.

Maluccio, John. 1998. "Endogeneity of Schooling in the Wage Function: Evidence from Rural Philippines", FCND Discussion Paper No. 54, International Food Policy Research Institute.

Mincer, Jacob. 1974. Schooling, Experience and Earnings, New York, Columbia University Press.

Nehru, Vikram, Eric Swanson, and Ashok Dubley. 1995. "A New Database on Human Capital Stock: Sources, Methodology, and Results", Journal of Development Economics 46 (April), pp. 379-401.

Park, Jin Heum. 1994. "Returns to Schooling: A Peculiar Deviation from Linearity", Working Paper 335, Industrial Relations Section, Princeton University.

Pritchett, Lant. 1996. "Where Has All the Education Gone?", The World Bank, Policy Research Working Paper 1581, Washington, D.C.

Psacharopoulos, George. 1973. Returns to Education: An International Comparison, San Francisco, Jossy-Bass-Elsevier. 
1981. "Returns to Education: An Updated International Comparison", Comparative Education 17: 321-341.

1985. "Returns to Education: A Further International Update and Implications", Journal of Human Resources 20, No. 4, 583-604.

-----. 1989. "Time Trends of the Returns to Education: Cross-National Evidence", Economics of Education Review 8, No. 3, pp. 225-231.

1994. "Returns to Investment in Education: A Global Update", World Development 22, No. 9, pp. 1325-43.

Strauss, John, and Duncan Thomas. 1995. "Human Resources: Empirical Modeling of Household and Family Decisions", in Hollis Burnley Chenery and T. N. Srinivasan, eds., Handbook of Development Economics, Vol. 3b., Amsterdam, North-Holland.

-------. 1996. "Wages, Schooling, and Background: Investments in Men and Women in Urban Brazil", in Nancy Birdsall, Barbara Bruns and Richard Sabot, eds., Opportunity Foregone: Education, Growth, and Inequality in Brazil, Baltimore, The Johns Hopkins University Press.

Tan, Jee-Peng and Vicente B. Paqueo. 1989. "The Economic Returns to Education in the Philippines”, International Journal of Educational Development 9, No. 3, 243-50.

Welch, Finis. 1975. "Human Capital Theory: Education, Discrimination, and Life Cycles", American Economic Review, Papers and Proceedings 65 (May), 63-73.

Willis, Robert J. 1986. "Wage Determinants: A Survey and Reinterpretations of Human Capital Earnings Functions", in Orley Ashenfelter and Richard Layard, eds., Handbook of Labor Economics, Volume 1, 525-602, Amsterdam, North Holland.

World Bank. 2000. "Philippines 2000: Social and Structural Review”, typescript. World Development Indicators database, various years. 
Table 1: Summary Statistics

\begin{tabular}{|c|c|c|c|}
\hline Variable & Median & Mean & $\begin{array}{l}\text { Standard } \\
\text { Deviation }\end{array}$ \\
\hline \multicolumn{4}{|c|}{ ALL MEN } \\
\hline Log Hourly Wage Rate (1998 Filipino pesos) & 2.75 & 2.71 & .859 \\
\hline Weekly Hours Worked & 43.69 & 41.12 & 15.08 \\
\hline Age & 33 & 34.29 & 12.38 \\
\hline Years of Completed Schooling & 9 & 8.78 & 3.56 \\
\hline \multicolumn{4}{|c|}{ MEN AGED 25 TO 65} \\
\hline Log Hourly Wage Rate (1998 Filipino pesos) & 2.89 & 2.86 & .821 \\
\hline Weekly Hours Worked & 44.31 & 42.34 & 14.25 \\
\hline Age & 38 & 38.96 & 9.77 \\
\hline Years of Completed Schooling & 10 & 9.06 & 3.62 \\
\hline \multicolumn{4}{|c|}{ MEN WITH AVAILABLE DATA ON PARENTAL EDUCATION } \\
\hline Log Hourly Wage Rate (1998 Filipino pesos) & 2.36 & 2.39 & .909 \\
\hline Weekly Hours Worked & 40.62 & 37.09 & 16.53 \\
\hline Age & 22 & 22.20 & 5.65 \\
\hline Years of Completed Schooling & 9 & 8.53 & 3.58 \\
\hline \multicolumn{4}{|c|}{ MEN WITH AVAILABLE DATA ON SIBLING EDUCATION AND EARNINGS } \\
\hline Log Hourly Wage Rate (1998 Filipino pesos) & 2.39 & 2.38 & .844 \\
\hline Weekly Hours Worked & 40.62 & 37.78 & 16.17 \\
\hline Age & 23 & 23.67 & 6.56 \\
\hline Years of Completed Schooling & 8 & 8.12 & 3.44 \\
\hline
\end{tabular}

Note: Author's calculations based on the APIS tapes, taking into account the weighted nature of the data. 
Table 2: Returns to Education, Spline Specification

\begin{tabular}{|c|c|c|c|}
\hline & \multicolumn{3}{|c|}{ Specification } \\
\hline & 1 & 2 & 3 \\
\hline \multirow[t]{2}{*}{ Experience } & $.043 * * *$ & $.044^{* * *}$ & $.036 * * *$ \\
\hline & $(.001)$ & $(.001)$ & $(.002)$ \\
\hline \multirow[t]{2}{*}{ Squared Experience (x 100) } & $-.060 * * *$ & $-.061 * * *$ & $-.050 * * *$ \\
\hline & $(.003)$ & $(.002)$ & $(.004)$ \\
\hline \multirow[t]{2}{*}{ Years of Completed Schooling } & $.062 * * *$ & $.054 * * *$ & $.058 * * *$ \\
\hline & $(.011)$ & $(.010)$ & $(.013)$ \\
\hline \multirow[t]{2}{*}{ Dummy for $S>=6(\mathrm{D6})$} & $.121 * * *$ & .031 & $.098 * *$ \\
\hline & $(.031)$ & $(.027)$ & $(.036)$ \\
\hline \multirow[t]{2}{*}{ D6 * (S-6) } & .008 & .008 & .008 \\
\hline & $(.013)$ & $(.011)$ & $(.015)$ \\
\hline \multirow[t]{2}{*}{ Dummy for $S>=10$ (D10) } & $.129 * * *$ & $.047^{*}$ & $.124 * * *$ \\
\hline & $(.025)$ & $(.021)$ & $(.030)$ \\
\hline \multirow[t]{2}{*}{ D10 * (S-10) } & $.043 * * *$ & $.058 * * *$ & $.042 * * *$ \\
\hline & $(.010)$ & $(.009)$ & $(.012)$ \\
\hline \multirow[t]{2}{*}{ Dummy for $S=15$} & $.276 * * *$ & $.269 * * *$ & $.288 * * *$ \\
\hline & $(.037)$ & $(.032)$ & $(.040)$ \\
\hline Provincial Dummies & No & Yes & No \\
\hline R-squared & .311 & .489 & .267 \\
\hline F-test & $48.37 * * *$ & $112.27^{* * *}$ & $46.81^{* * * *}$ \\
\hline Number of observations & 21,765 & 21,765 & 16,738 \\
\hline \multirow[t]{2}{*}{ Experience } & $.043 * * *$ & $.044 * * *$ & $.036 * * *$ \\
\hline & $(.001)$ & $(.001)$ & $(.002)$ \\
\hline \multirow[t]{2}{*}{ Squared Experience (x 100) } & $-.060 * * *$ & $-.060 * * *$ & $-.049 * * *$ \\
\hline & $(.003)$ & $(.002)$ & $(.004)$ \\
\hline \multirow[t]{2}{*}{ Years of Completed Schooling } & $.094 * * *$ & $.062 * * *$ & $.084 * * *$ \\
\hline & $(.006)$ & $(.005)$ & $(.007)$ \\
\hline \multirow[t]{2}{*}{ D6 * (S-6) } & .006 & .007 & .009 \\
\hline & $(.008)$ & $(.007)$ & $(.009)$ \\
\hline \multirow[t]{2}{*}{ D10* (S-10) } & $.067 * * *$ & $.102 * * *$ & $.072 * * *$ \\
\hline & $(.006)$ & $(.005)$ & $(.007)$ \\
\hline Provincial Dummies & No & Yes & No \\
\hline R-squared & .308 & .487 & .264 \\
\hline F-test & $81.80^{* * *}$ & $263.40 * * *$ & $84.99^{* * *}$ \\
\hline Number of observations & 21,765 & 21,765 & 16,738 \\
\hline
\end{tabular}

Note: The dependent variable is the log of hourly wages. Coefficients and standard errors corrected for heteroskedasticity and clustering are reported in parentheses. Specifications 1 and 2 include all men who report earning wage income; Specification 3 is limited to men aged 25 to 65 . A constant was estimated but is not reported.

F-test: F-test in top panel is joint F-test on the two interaction terms and the three dummy variables, F-test in bottom panel is joint F-test on the two interaction terms only.

${ }^{*}$ Significant at the $5 \%$ level; ** Significant at the $1 \%$ level; $* * *$ Significant at the $0.1 \%$ level. 
Table 3: Returns to Education, Semi-Parametric Specification

\begin{tabular}{|c|c|c|c|}
\hline & & ecificatio & \\
\hline & 1 & 2 & 3 \\
\hline Experience & $.043^{* * *}$ & $.044 * * *$ & $.036 * * *$ \\
\hline & $(.001)$ & $(.001)$ & $(.002)$ \\
\hline Squared Experience (x 100) & $-.060 * * *$ & $-.061 * * *$ & $-.050 * * *$ \\
\hline & $(.003)$ & $(.002)$ & $(.000)$ \\
\hline $\mathbf{S}=\mathbf{1}$ & .100 & .089 & -.049 \\
\hline & $(.153)$ & $(.128)$ & $(.164)$ \\
\hline 2 & .024 & .052 & -.001 \\
\hline & $(.072)$ & $(.060)$ & $(.079)$ \\
\hline 3 & $.138 * *$ & .110 & $.180 * *$ \\
\hline & $(.049)$ & $(.042)$ & $(.058)$ \\
\hline 4 & .017 & .033 & -.014 \\
\hline & $(.037)$ & $(.030)$ & $(.044)$ \\
\hline 5 & .061 & .025 & .072 \\
\hline & $(.033)$ & $(.029)$ & $(.040)$ \\
\hline 6 & $.193 * * *$ & $.102 * * *$ & $.163^{* * *}$ \\
\hline & $(.028)$ & $(.023)$ & $(.031)$ \\
\hline 7 & .049 & $.087^{* * *}$ & .021 \\
\hline & $(.029)$ & $(.025)$ & $(.036)$ \\
\hline 8 & $.072^{*}$ & .026 & $.088^{*}$ \\
\hline & $(.033)$ & $(.028)$ & $(.040)$ \\
\hline 9 & $.097^{* *}$ & $.077 * *$ & $.103^{* *}$ \\
\hline & $(.030)$ & $(.024)$ & $(.034)$ \\
\hline 10 & $.187^{* * * *}$ & $.105 * * *$ & $.175^{* * *}$ \\
\hline & $(.023)$ & $(.019)$ & $(.026)$ \\
\hline 11 & $.086 * *$ & $.125 * * *$ & .084 \\
\hline & $(.033)$ & $(.028)$ & $(.038)$ \\
\hline 12 & $.141^{* * *}$ & $.119 * * *$ & $.113^{* *}$ \\
\hline & $(.037)$ & $(.031)$ & $(.042)$ \\
\hline 13 & $.110^{* *}$ & $.132 * * *$ & $.142 * * *$ \\
\hline & $(.037)$ & $(.031)$ & $(.039)$ \\
\hline 14 & .118 & .055 & .128 \\
\hline & $(.073)$ & $(.062)$ & $(.078)$ \\
\hline 15 & $.382 * * *$ & $.441 * * *$ & $.361 * * *$ \\
\hline & $(.070)$ & $(.059)$ & $(.074)$ \\
\hline Provincial Dummies & No & Yes & No \\
\hline R-squared & .312 & .489 & .268 \\
\hline Number of observations & 21,765 & 21,765 & 16,738 \\
\hline
\end{tabular}

Note: The dependent variable is the log of hourly wages. Coefficients and standard errors corrected for heteroskedasticity and clustering are reported in parentheses. Specifications 1 and 2 include all men who report earning wage income; Specification 3 is limited to men aged 25 to 65 ; Specifications 4 and 5 are limited to men whose relationship to the household head is "son" in households in which both the household head and his or her spouse are members and report their education levels. A constant was estimated but is not reported.

* Significant at the $5 \%$ level; ** Significant at the $1 \%$ level; *** Significant at the $0.1 \%$ level. 


\section{Table 4: Returns to Education, Spline Specification, Controls for Parental Education and "Within" Estimators}

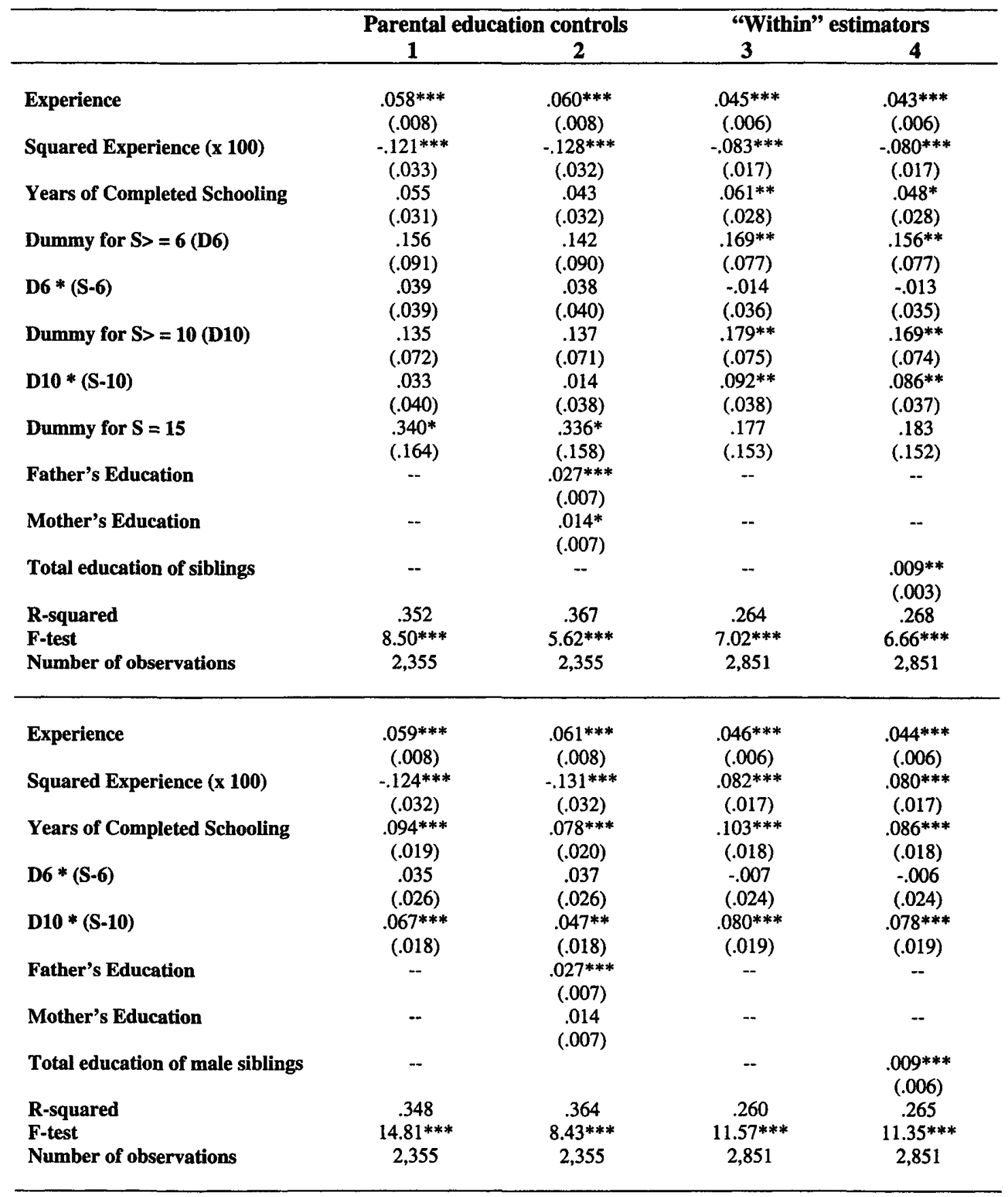

Note: See note at foot of Table 2 for explanation of coefficients, standard errors, test statistics, and levels of significance. Specifications 1 and 2 are limited to men whose relationship to the household head is "son" in households in which both the household head and his spouse are members and report their education levels. Specifications 3 and 4 are limited to men in households with at least two wage-earning male siblings. Provincial dummies are not included in the regressions. 
Table 5: Returns to Education, Semi-Parametric Specification, Controls for Parental Education and "Within" Estimators

\begin{tabular}{|c|c|c|c|c|}
\hline & \multicolumn{2}{|c|}{ Parental education controls } & \multicolumn{2}{|c|}{ "Within" estimators } \\
\hline & 1 & 2 & 3 & 4 \\
\hline \multirow[t]{2}{*}{ Experience } & $.058 * * *$ & $.060 * * *$ & $.045^{* * *}$ & $.044^{* * * *}$ \\
\hline & $(.008)$ & $(.008)$ & $(.006)$ & $(.006)$ \\
\hline \multirow[t]{2}{*}{ Squared Experience (x 100) } & $-.123 * * *$ & $-.129 * * *$ & $-.080 * * *$ & $-.080 * * *$ \\
\hline & $(.033)$ & $(.032)$ & $(.017)$ & $(.017)$ \\
\hline \multirow[t]{2}{*}{$S=1$} & -.127 & -.197 & -.160 & -.14 .5 \\
\hline & $(.272)$ & $(.282)$ & $(.290)$ & $(.292)$ \\
\hline \multirow[t]{2}{*}{2} & .169 & .187 & .194 & .159 \\
\hline & $(.224)$ & $(.238)$ & $(.230)$ & $(.229)$ \\
\hline \multirow[t]{2}{*}{3} & -.093 & -.120 & -.017 & -.018 \\
\hline & $(.129)$ & $(.133)$ & $(.114)$ & $(.114)$ \\
\hline \multirow[t]{2}{*}{4} & .124 & .117 & .103 & .088 \\
\hline & $(.104)$ & $(.104)$ & $(.080)$ & $(.080)$ \\
\hline \multirow[t]{2}{*}{5} & .078 & .065 & .057 & .045 \\
\hline & $(.087)$ & $(.086)$ & $(.072)$ & $(.072)$ \\
\hline \multirow[t]{2}{*}{6} & $.208^{*}$ & $.182^{*}$ & $222 * * *$ & $.199 * * *$ \\
\hline & $(.082)$ & $(.081)$ & $(.068)$ & $(.069)$ \\
\hline \multirow[t]{2}{*}{7} & .005 & -.011 & .051 & .037 \\
\hline & $(.075)$ & $(.074)$ & $(.069)$ & $(.068)$ \\
\hline \multirow[t]{2}{*}{8} & .153 & .136 & .099 & .091 \\
\hline & $(.084)$ & $(.083)$ & $(.079)$ & $(.078)$ \\
\hline \multirow[t]{2}{*}{9} & .137 & .132 & -.034 & -.046 \\
\hline & $(.081)$ & $(.080)$ & $(.082)$ & $(.082)$ \\
\hline \multirow[t]{2}{*}{10} & $.206 * *$ & $.191 * *$ & $.257 * * *$ & $.236^{* * * *}$ \\
\hline & $(.066)$ & $(.065)$ & $(.069)$ & $(.069)$ \\
\hline \multirow[t]{2}{*}{11} & .065 & .016 & $.157^{*}$ & .139 \\
\hline & $(.091)$ & $(.090)$ & $(.091)$ & $(.088)$ \\
\hline \multirow[t]{2}{*}{12} & .163 & .140 & .151 & .142 \\
\hline & $(.109)$ & $(.108)$ & $(.109)$ & $(.108)$ \\
\hline \multirow[t]{2}{*}{13} & .231 & .217 & -.051 & -.052 \\
\hline & $(.203)$ & $(.196)$ & $(.181)$ & $(.181)$ \\
\hline \multirow[t]{2}{*}{14} & .047 & -.004 & $.585 * *$ & $.476^{*}$ \\
\hline & $(.450)$ & $(.401)$ & $(.254)$ & $(.257)$ \\
\hline \multirow[t]{2}{*}{15} & .466 & .427 & .031 & .092 \\
\hline & $(.409)$ & $(.358)$ & $(.199)$ & $(.198)$ \\
\hline \multirow[t]{2}{*}{ Father's education } & -- & $.027 * * *$ & $\ldots$ & - \\
\hline & & $(.007)$ & & \\
\hline \multirow[t]{2}{*}{ Mother's education } & -- & $.015^{*}$ & -- & -- \\
\hline & & $(.007)$ & & \\
\hline Total education of male siblings & - & - & -- & .008 \\
\hline R-squared & .353 & .369 & .266 & .269 \\
\hline Number of observations & 2,355 & 2,355 & 2,851 & 2,851 \\
\hline
\end{tabular}

Note: See note at foot of Table 3 for explanation of coefficients, standard errors, test statistics, and levels of significance. Specifications 1 and 2 are limited to men whose relationship to the household head is "son" in households in which both the household head and his spouse are members and report their education levels. Specifications 3 and 4 are limited to men in households with at least two wage-earning male siblings. Provincial dummies are not included in the regressions. 
Table 6: Direct private costs of education, by education level and consumption quintile

\begin{tabular}{|c|c|c|c|c|c|c|c|}
\hline & & \multirow[t]{2}{*}{ All HH } & \multicolumn{5}{|c|}{ Quintile } \\
\hline & & & $\begin{array}{c}1 \\
\text { (poorest) }\end{array}$ & 2 & 3 & 4 & $\begin{array}{c}5 \\
\text { (richest) }\end{array}$ \\
\hline \multirow{2}{*}{ Primary } & Unit costs (per student) & 898 & 270 & 469 & 771 & 1589 & 5536 \\
\hline & $\%$ of total HH consumption & $0.7 \%$ & $0.6 \%$ & $0.7 \%$ & $0.9 \%$ & $1.3 \%$ & $2.0 \%$ \\
\hline \multirow{2}{*}{ Secondary } & Unit costs (per siudent) & 2745 & 661 & 1263 & 1696 & 3052 & 7295 \\
\hline & $\%$ of total HH consumption & $2.0 \%$ & $1.5 \%$ & $1.9 \%$ & $1.9 \%$ & $2.4 \%$ & $2.6 \%$ \\
\hline \multirow{2}{*}{ Tertiary } & Unit costs (per student) & 13334 & 1879 & 3487 & 5690 & 8512 & 20355 \\
\hline & $\%$ of total $\mathrm{HH}$ consumption & $9.7 \%$ & $4.1 \%$ & $5.3 \%$ & $6.5 \%$ & $6.8 \%$ & $7.2 \%$ \\
\hline
\end{tabular}

Note: Quintiles are 1997 per capita consumption quintiles. 
Figure 1: Density estimates of Mean Log Hourly Wages

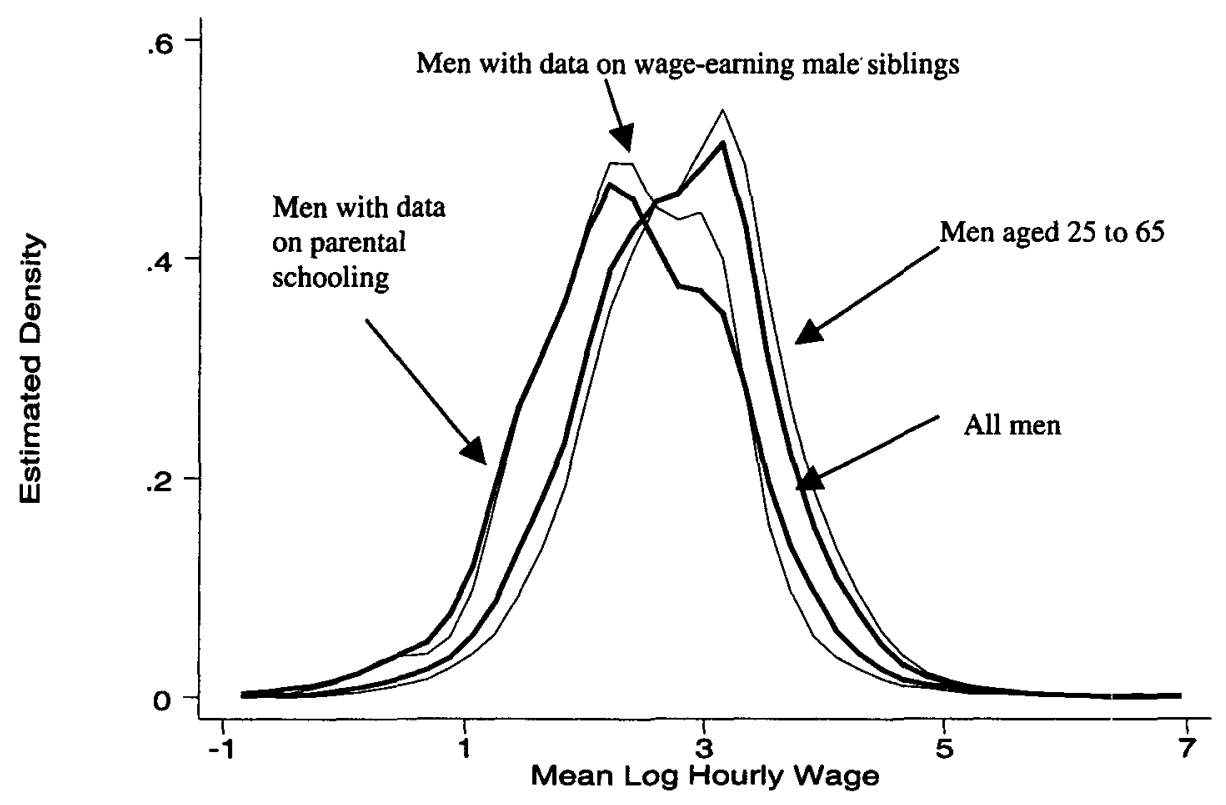

Figure 2: Histogram of Years of Completed Schooling (all men)

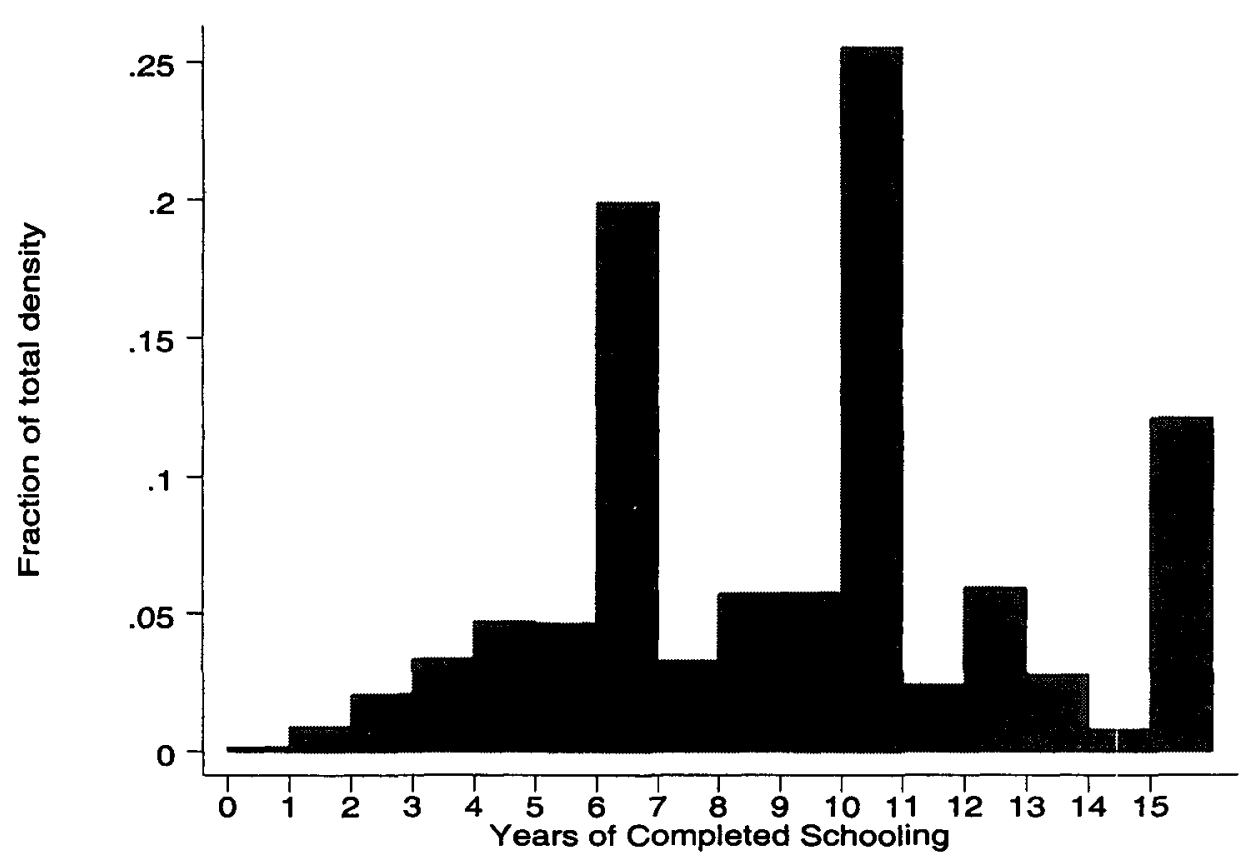




\section{Figure 3: Mean Log Hourly Wage, by Years of Completed Schooling}

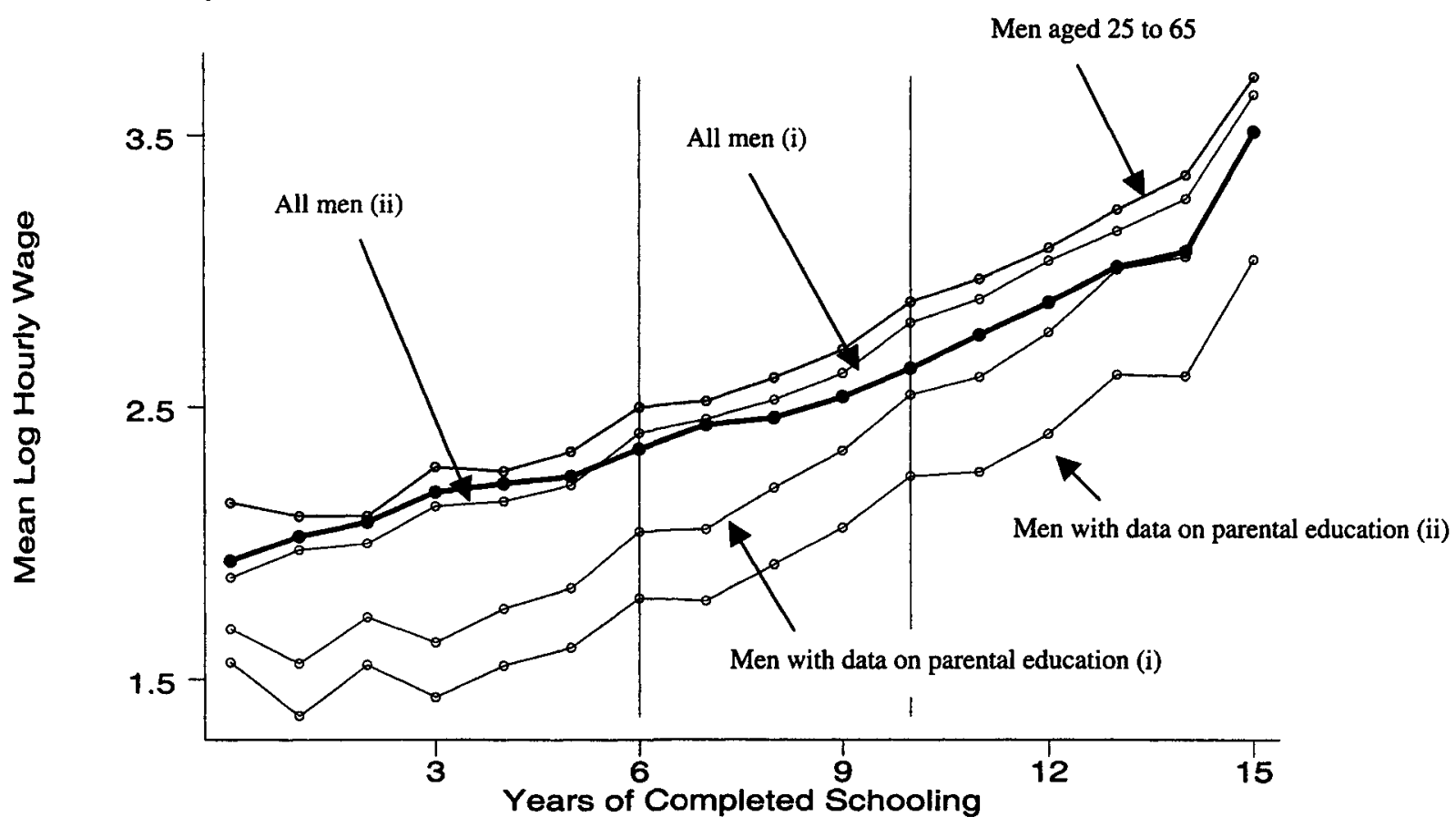

Note: Coefficients for line labeled "all men (i)" come from a regression without provincial dummies, while coefficients for line labeled "all men (ii)" are from a regression with provincial dummies. Coefficients for line labeled "Men with data on parental education (i)" come from a regression limited to the sample of men for whom data on parents' schooling are available, but do not include controls for parental schooling; coefficients for line labeled "Men with data on parental education (ii)" come from a regression with this same sample which includes controls for parental education. The intercept for each of the lines includes the effect of experience at the mean of the sample. 
Figure 4: Mean Log Hourly Wage, by Experience Category and Years of Completed Schooling
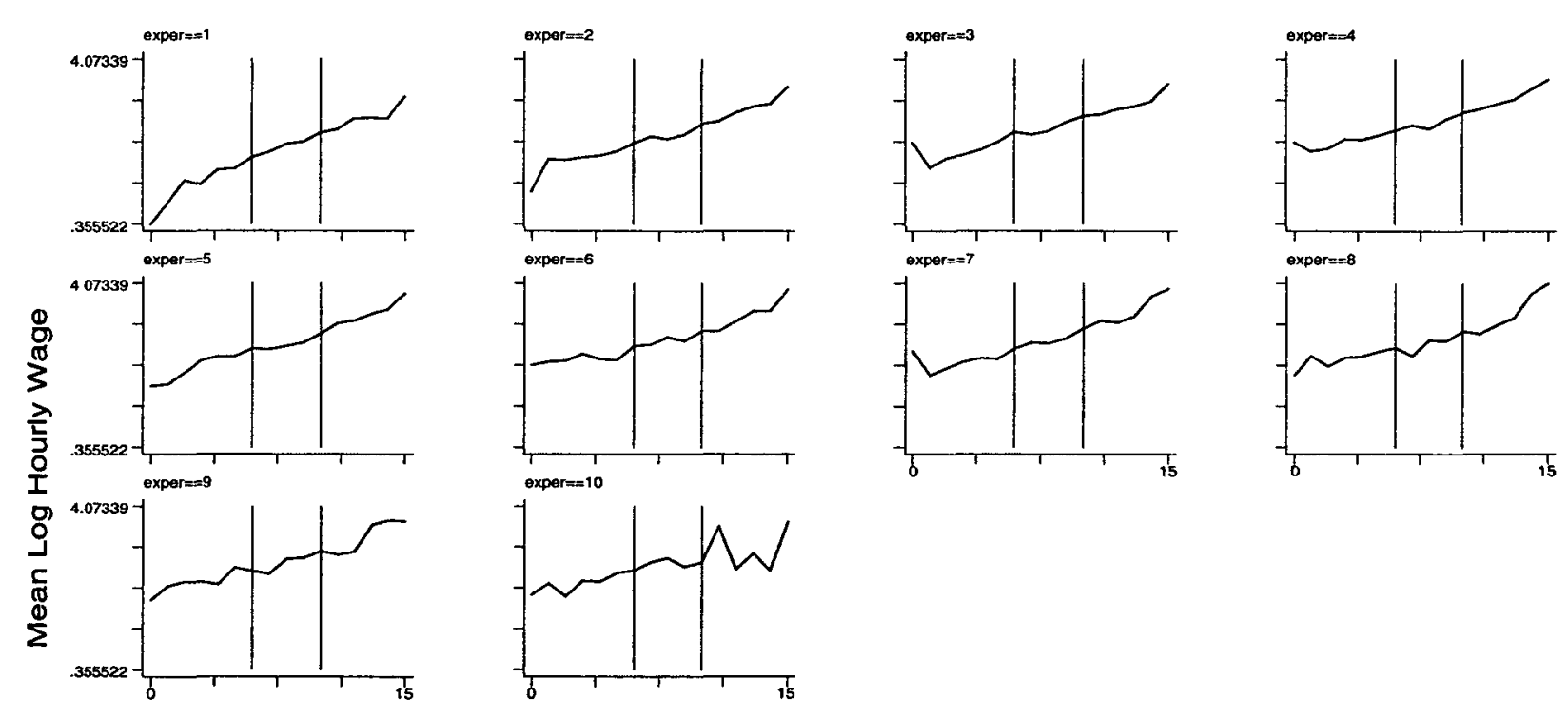

Years of Completed Schooling 
Figure 5: Hypothetical Distribution of Ability, by Socio-Economic Class and Years of Completed Schooling

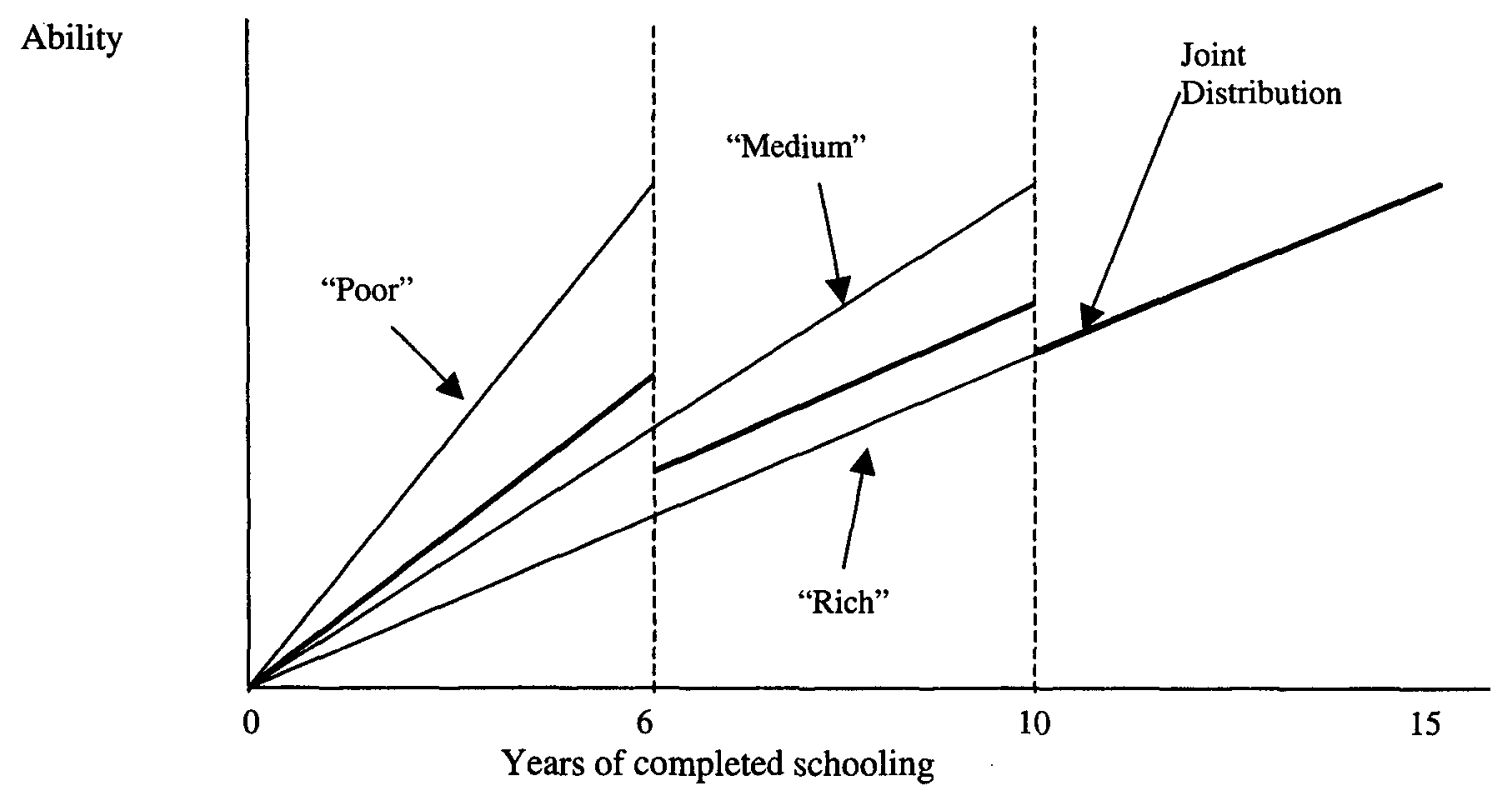





\section{Policy Research Working Paper Series}

\begin{tabular}{|c|c|c|c|c|}
\hline & Title & Author & Date & for paper \\
\hline WPS2542 & $\begin{array}{l}\text { Checks and Balances, Private } \\
\text { Information, and the Credibility of } \\
\text { Monetary Commitments }\end{array}$ & $\begin{array}{l}\text { Philip Keefer } \\
\text { David Stasavage }\end{array}$ & February 2001 & $\begin{array}{l}\text { P. Sintim-Aboagye } \\
37644\end{array}$ \\
\hline WPS2543 & $\begin{array}{l}\text { When Do Special Interests Run } \\
\text { Rampant? Disentangling the Role in } \\
\text { Banking Crises of Elections, Incomplete } \\
\text { Information, and Checks and Balances }\end{array}$ & Philip Keefer & February 2001 & $\begin{array}{l}\text { P. Sintim-Aboagye } \\
37644\end{array}$ \\
\hline WPS2544 & $\begin{array}{l}\text { The Uniqueness of Short-Term } \\
\text { Collateralization }\end{array}$ & Leora Klapper & February 2001 & $\begin{array}{l}\text { A. Yaptenco } \\
31823\end{array}$ \\
\hline WPS 2545 & $\begin{array}{l}\text { Financing the Future: Infrastructure } \\
\text { Needs in Latin America, 2000-05 }\end{array}$ & Marianne Fay & February 2001 & $\begin{array}{l}\text { A. François } \\
37841\end{array}$ \\
\hline WPS2546 & $\begin{array}{l}\text { Gender Dimensions of Pension } \\
\text { Reform in the Former Soviet Union }\end{array}$ & $\begin{array}{l}\text { Paulette Castel } \\
\text { Louise Fox }\end{array}$ & February 2001 & $\begin{array}{l}\text { J. Smith } \\
87215\end{array}$ \\
\hline WPS2547 & $\begin{array}{l}\text { The Design of Incentives for Health } \\
\text { Care Providers in Developing } \\
\text { Countries: Contracts, Competition, } \\
\text { and Cost Control }\end{array}$ & $\begin{array}{l}\text { Jeffrey S. Hammer } \\
\text { William G. Jack }\end{array}$ & February 2001 & $\begin{array}{l}\text { H. Sladovich } \\
37698\end{array}$ \\
\hline WPS2548 & $\begin{array}{l}\text { International Provision of Trade } \\
\text { Services, Trade, and Fragmentation }\end{array}$ & Alan V. Deardorff & February 2001 & $\begin{array}{l}\text { L. Tabada } \\
36896\end{array}$ \\
\hline WPS2549 & $\begin{array}{l}\text { Measuring Poverty Dynamics and } \\
\text { Inequality in Transition Economies: } \\
\text { Disentangling Real Events from } \\
\text { Noisy Data }\end{array}$ & Erzo F. P. Luttmer & February 2001 & $\begin{array}{l}\text { C. Wodon } \\
32542\end{array}$ \\
\hline WPS2550 & $\begin{array}{l}\text { Measuring Equity in Health Care } \\
\text { Financing: Reflections on (and } \\
\text { Alternatives to) the World Health } \\
\text { Organization's Fairness of Financing } \\
\text { Index }\end{array}$ & Adam Wagstaff & February 2001 & $\begin{array}{l}\text { A. Maranon } \\
38009\end{array}$ \\
\hline WPS2551 & $\begin{array}{l}\text { Infrastructure Coverage and the } \\
\text { Poor: A Global Perspective }\end{array}$ & $\begin{array}{l}\text { Kristin Komives } \\
\text { Dale Whittington } \\
\text { Xun Wu }\end{array}$ & February 2001 & $\begin{array}{l}\text { S. Minovi } \\
30012\end{array}$ \\
\hline WPS2552 & $\begin{array}{l}\text { Inventories in Developing Countries: } \\
\text { Levels and Determinants-a Red Flag } \\
\text { For Competitiveness and Growth }\end{array}$ & $\begin{array}{l}\text { J. Luis Guasch } \\
\text { Joseph Kogan }\end{array}$ & February 2001 & $\begin{array}{l}\text { J. Troncoso } \\
37826\end{array}$ \\
\hline WPS2553 & $\begin{array}{l}\text { The Value of Relationship Banking } \\
\text { during Financial Crises: Evidence } \\
\text { from the Republic of Korea }\end{array}$ & $\begin{array}{l}\text { Giovanni Ferri } \\
\text { Tae Soo Kang } \\
\text { In-June Kim }\end{array}$ & February 2001 & $\begin{array}{l}\text { A. Yaptenco } \\
31823\end{array}$ \\
\hline
\end{tabular}




\section{Policy Research Working Paper Series}

Title

WPS2554 Administrative Costs and the Organization of Individual Retirement Account Systems: A Comparative Perspective

WPS2555 Implicit Pension Debt, Transition Cost, Options, and Impact of China's Pension Reform: A Computable General Equilibrium Analysis

WPS2556 Household Strategies for Coping with Poverty and Social Exclusion in Post-Crisis Russia

WPS2557 Decentralization and Accountability: Stuti Khemani Are Voters More Vigilant in Local than in National Elections?

WPS2558 Growth, Inequality, and Poverty: Martin Ravallion Looking beyond Averages

WPS2559 Deposit Insurance as Private Club: Thorsten Beck Is Germany a Model?

WPS2560 Catastrophe Risk Management: Using Alternative Risk Financing and Insurance Pooling Mechanisms

WPS2561 Democracy and Income Inequality: An Empirical Analysis

WPS2562 Decomposing World Income Distribution: Does the World Have a Middle Class?

WPS2563 A Race to the Top? A Case Study of Food Safety Standards and African Exports

WPS2564 Economic Analysis of World Bank Education Projects and Project Outcomes

WPS2565 Does Fiscal Decentralization Improve Health Outcomes? Evidence from a Cross-Country Analysis
Author

Estelle James James Smalhout Dimitri Vittas

Yan Wang

Dianqing $\mathrm{Xu}$

Zhi Wang

Fan Zhai

Michael M. Lokshin

Ruslan Yemtsov

John D. Pollner

Mark Gradstein

Branko Milanovic

Yvonne Ying

Branko Milanovic

Shlomo Yitzhaki

Tsunehiro Otsuki

John S. Wilson

Mirvat Sewadeh

Ayesha Yaqub Vawda

Peter Moock

J. Price Gittinger

Harry Anthony Patrinos

David A. Robalino

Oscar F. Picazo

Albertus Voetberg
Date

February 2001

February 2001

February 2001

February 2.001

February 2001

February 2001

February 2.001

March 2001

March 2001

March 2001

March 2001

March 2001

87954
O. Picazo

Contact for paper

A. Yaptenco 31823

A. Datoloum 36334

P. Sader 33902

H. Sladovich 37698

P. Sader 33902

P. Sintim-Aboagye 38526

J. Pollner 30079

P. Sader 33902

P. Sader 33902

L. Tabada 36896

E. James 31756 